\title{
The effect of surface fire on tree ring growth of Pinus radiata trees
}

\author{
Thomas Seifert $^{1} \cdot$ Martina Meincken $^{1} \cdot$ Benedict O Odhiambo ${ }^{1}$
}

Received: 25 May 2015 / Accepted: 28 November 2016 / Published online: 14 April 2017

(C) INRA and Springer-Verlag France 2017

\begin{abstract}
- Key message Pinus radiata trees showed significantly reduced basal area increments and increased latewood/ earlywood ratios, when their stem was charred by surface fires even if no needle damage occurred. An interaction of fire damage and precipitation on growth was observed.

- Context Heat from forest fires is able to penetrate beyond the bark layer and damage or completely kill a tree's cambium. Short-term growth reductions following surface fires have been reported for some species. However, most studies have in common that they describe a compound effect of stem and foliage damage.

- Aims This study investigated the impact of surface fires on the radial growth of Pinus radiata, where only the stem of trees was charred, while no needle damage was recorded.
\end{abstract}

\section{Handling Editor: Eric Rigolot}

Contribution of the co-authors Benedict Odhiambo ( $\mathrm{PhD}$ student): designed experiment, wrote substantial parts of the paper, and did most of the statistical analysis.

Martina Meincken (co-supervisor): provided supervision in sampling and analysis and wrote and edited parts of the paper.

Thomas Seifert (supervisor): provided supervision in sampling and analysis, wrote substantial parts of the paper, and coordinated the research project.

Electronic supplementary material The online version of this article (doi:10.1007/s13595-016-0608-8) contains supplementary material, which is available to authorized users.

Thomas Seifert

seifert@sun.ac.za

Benedict O Odhiambo

beneodhis@yahoo.co.uk

1 Department of Forest and Wood Science, Stellenbosch University, Stellenbosch, South Africa
- Methods Tree ring measurements were performed on cores obtained at breast height. Analysis of variance and tests, based on annual basal area increment values were calculated to quantify pre- and post-fire growth differences of tree ring width and latewood/earlywood ratios.

- Results The analysis revealed significant growth reductions following a surface fire on P. radiata in the year on which the fire occurred as well as in the following year. As a consequence of the fire, basal area increment and latewood/ earlywood ratios were significantly reduced. An interaction of fire damage and precipitation on growth was observed.

- Conclusion The obtained results show how fires without crown damage can affect growth and tree ring structure of $P$. radiata trees and indicate that stem char could be associated with a significant decrease in ring width and latewood/ earlywood ratio.

Keywords Monterey pine · Growth recovery $\cdot$ Latewood/ earlywood ratio $\cdot$ Tree ring analysis $\cdot$ Abiotic stress $\cdot$ Multiple stresses $\cdot$ Drought stress

\section{Introduction}

Fire is a key ecosystem process (Pyne et al. 1996, De Bano et al. 1998) and strongly influences trees in fire prone environments. It impacts on mortality rates and causes stress to surviving trees (Ducrey et al. 1996; Hood et al. 2007; Varner et al. 2009). Typically trees are not only affected locally at the damaged tissue but also show a systemic reaction, which is reflected in annual ring widths of the stem (Schweingruber 1993, Grissino-Mayer 2010; Fulé 2010). In this context, fire resistance mechanisms of trees are highly species-specific (Odhiambo et al. 2014; Wesolowski et al. 2014, Arbelley et al. 2014a, 2014b; Smith et al. 2016). It might be the case 
that increased frequencies of "high fire risk" weather conditions driven by higher temperatures and erratic rainfall due to climate change will lead to higher fire frequencies (de Ronde 2008a; Aldersley et al. 2011). However, the climate-vegetation-fire interrelations are complex (Macias Fauria et al. 2011; Harris et al. 2016). Thus, current models are not fully capable of addressing these interrelations in order to predict how climate change might impact on the major chronological events involved with a fire as defined by Macias Fauria et al. (2011), which are fuel drying, ignition, spread, and extinction. One might want to add fuel buildup in this context. So, many observations still need to be integrated in a bigger picture (Macias Fauria et al. 2011; Harris et al. 2016) and remain speculative in their true effect. Climate change for example might extend the length of the fire season in some areas (Westerling et al. 2006) and lead to increased burnt areas (Mann et al. 2016). Also, the anthropogenic factor additionally influences fire probabilities and climate projections still contain a substantial amount of uncertainty, which makes reliable projections difficult (Mann et al. 2016). It is obvious that higher fire frequencies are likely to affect tree mortality and to cause negative growth responses in surviving trees (van Mantgem et al. 2009; de Ronde 2008a), in particular if vegetation has not yet adapted to the changed climatic conditions (Parks et al. 2016). This has prompted the need for an increased awareness on the negative growth impacts of fires on trees. Different fire types, such as surface fires or crown fires, as defined by Gill (1977), Brown (1995), and Newton (2007), might also lead to different responses. Hood et al. $(2007,2008)$ pointed out the differences of fire effects with regard to the damaged tree parts and distinguished bole char and needle scorch. However, based on the existing body of literature on Pinus radiata, limited information is available on how bole char specifically affects the growth of this species. As a result, this study concentrated on surface fire effects on stems of $P$. radiata.

The trunks of most trees possess traits that protect the cambium against heating by forest fires (Bauer et al. 2010). Therefore, mature trees with thick bark are typically not overly affected by such fires if the fire duration is not too long (Fernandes et al. 2008). Heat produced by hotter fires (Bauer et al. 2010; Wesolowski et al. 2014) can penetrate more quickly beyond the bark layer and damage or completely kill even a mature tree's cambium (Dickinson and Johnson 2001; Michaletz and Johnson 2007; Vega et al. 2011). However, also a low intensity fires can cause cambial damage if the tree is exposed to it long enough. For this reason, the impact of stress on tree growth should be generally characterized based on its intensity, duration, frequency, and time of occurrence (Rötzer et al. 2012).

Fire-affected trees often have distinct marks. In the specific case of surface fires, typical char marks can be seen for several growth seasons at the stem base. However, a charred bark does not necessarily imply an effect on the cambium. As mentioned before, trees are able to withstand heat because of their heat insulating bark layers (Odhiambo et al. 2014, Wesolowski et al. 2014). If the heat penetrated to the cambium, it eventually kills it. Where the cambium is killed, scars in the wood are often formed as permanent marks of the fire event (Dickinson and Johnson 2001; Newton 2007; Michaletz and Johnson 2007; Smith et al. 2016).

In order to predict the growth response after fire events, it is important to understand the reaction of the tree to fire. While the various injuries such as needle, cambium, and xylem damage are better understood, in particular the concepts of interaction of injuries lag behind. This leads to a situation where reported results are conflicting at first glance. Some reports highlight short-term growth reductions following surface fire damage, for example by Elliott et al. (2002) on Pinus strobus and Ford et al. (2010) on long leafed pine (Pinus palustris). A study on Pinus ponderosa provided conflicting findings with both, growth reductions and increases after surface fires of varying frequency (Peterson et al. 1994). Hempson et al. (2014), Bauer et al. (2010), and Ducrey et al. (1996) reported low-intensity surface fires not to have a negative impact on growth of Pinus halepensis. Given the conflicting results of previous studies, despite a body of literature on the subject, it can be stated that there is a lack of understanding of the impact of surface fires on tree growth.

It has been reported that cambial death around the entire bole circumference disturbs water and nutrient supply to the leaves, while at the same time restricting translocation of photosynthates to the roots due to damaged phloem and xylem tissues. This results, eventually, in the death of the tree (Rozas et al. 2011; Ducrey et al. 1996). Recent evidence suggests a response prior to cambial death. Disruptions in the water transport by air seed cavitation and heat-induced conduit wall deformation were identified as potential reasons for stress, which are the cause for reduced sapwood conductivity (Balfour and Midgley 2006, Michaletz et al. 2012). There is evidence that higher temperatures can inflict damages to plant cells either indirectly, following metabolic changes, or directly by protein denaturation, altered lipid mobility or chemical decomposition (Whelan 1995). Fire can also lead to mechanical stress resulting in deformed tracheids. The reason is a softened cellulose structure due to heat, so that the tensile forces of the xylem sap exert stresses on the conduit walls, which leads to their deformation (see Michaletz et al. 2012). These interruptions to normal biophysical and biochemical functions may reduce the photosynthetic rate. The reactions of a tree following trunk damage also involve a series of defense processes including wound closure, compartmentalization of decay, and formation of wound healing callus tissue (Blanchette 1992; Larson 1994; Fink 1999; Seifert et al. 2010, Smith et al. 2016). These defense and healing processes are not only costly for the tree (Rötzer et al. 2012), but occur also 
at the expense of water transport (Schweingruber 2007) and might reduce the rate of photosynthesis by stomatal closure.

The potential impact of reduced water and nutrient supply, as well as photosynthate translocation due to an affected cambium, xylem, and phloem could potentially impact growth. However, how to best link the observed processes with the resulting growth reactions is still an open debate.

In the formation of wood after a fire, the higher temperatures seem to mainly cause tracheid enlargement and firedamaged trees are prone to forming cell walls consisting only of the middle lamella and primary walls (Larson 1994; Vaganov et al. 2004). These changes of wood structure and chemistry (Arbelley et al. 2014b), together with energy diverted to wound occlusion and defense (Smith et al. 2016), could potentially slow future tree growth. Recent results of Arbelley et al. (2014a) provided proof that conifers formed more but smaller tracheids, which the authors attributed to the trade-off between hydraulic safety and hydraulic efficiency. This means a tree recovering from fire damage will have to build up conductivity first with new xylem to reach the level of xylem conductivity it had before the fire. According to the optimal partitioning theory, trees balance their partitioning into fine roots and foliage in an optimal way (Hertel et al. 2013). Additionally, the water conducting area in the sapwood is adapted to meet the demands of water transport between fine roots and foliage (Shinozaki et al. 1964a, 1964b). It can be expected that if a tree experiences biophysical or biochemical disruptions at the trunk caused by stem char, the effect would also be reflected in the tree ring widths even higher up in the stem. It may also affect the proportions of early and latewood. Studies on systemic reactions of conifers to other abiotic stressors, such as ozone, have shown that the earlywood width, which is generally more plastic than the latewood width, was decreased overproportionally (Makkonen et al. 2016). The timing of the fire event within the vegetation period seems to affect the reaction of the latewood percentage (Drobyshev et al. 2004).

There is evidence that diameter growth is typically mostly affected in the year following a fire event (Ford et al. 2010). The reduction is described as short term, lasting only 13 years, after which growth rates return to approximately pre-fire levels (e.g., Murphy et al. 2010; Goldammer 2007; Werner 2005; Hoffmann and Solbrig 2003; Werner et al. 2006; Williams et al. 1999). This assumption is mainly based on observations of the impact of crown scorch, where photosynthetic capacity is directly destroyed (Wallin et al. 2003). The growth reduction can be seen as an abrupt narrowing of growth rings for several years after the fire (Stahlea et al. 1999; Schweingruber 1993). However, it is not entirely clear if surface fires would also cause a similar damage if needle scorch is absent.
This study seeks to investigate possible growth reduction trends following surface fire damage on $P$. radiata in South Africa. Various studies have been conducted to evaluate wildfire damage in commercial even-aged pine plantations in Southern Africa (e.g., de Ronde 2008c; de Ronde et al. 2004a; de Ronde and du Plessis 2002; de Ronde et al. 1986), but no succinct attempt has been made to summarize species-specific guidelines for wildfire damage assessment in such plantation stands. Such knowledge is important for improved understanding of the short- and longer-term effects of fire on the species. P. radiata that was stem charred by surface fire, but was not exposed to needle scorch, was sampled as a major commercial plantation species.

In this study, ring width measurements on $P$. radiata were used to determine the impact of surface fires. To focus on the effect that surface fires without crown scorch have on tree growth, only trees were selected that were exposed to heat at stem level, but gave no indication of additional crown damage. The tree ring widths after the fire incident were compared with those of unburnt trees of the same stand to assess possible growth effects with the null hypothesis that unburnt and stem charred trees grow in the same way.

The following hypotheses were tested:

\section{H1. Basal area increment (iBA) of stem charred P. radiata is} not affected.

Conditional that $\mathrm{H} 1$ is rejected:

H2. The stem char does not affect the ratios of latewood and earlywood.

\section{Material and methods}

\subsection{Study site}

The study was conducted at a $P$. radiata plantation in the Jonkershoek valley in the Western Cape Province, South Africa $\left(33^{\circ} 57^{\prime} \mathrm{S}, 18^{\circ} 55^{\prime} \mathrm{E}\right)$. The area experiences a typical Mediterranean climate with warm, dry summers and wet, temperate winters. In the summer, temperature averages $22{ }^{\circ} \mathrm{C}$ and drops to around $10{ }^{\circ} \mathrm{C}$ in winter (van Wilgen et al. 1990; van Wilgen 1982). The mean annual precipitation is about $884 \mathrm{~mm}$ per year, with substantial fluctuations between years, ranging from $464 \mathrm{~mm}$ in 2004 to $1586 \mathrm{~mm}$ annually in 1977 (Grab and Craparo 2011).

The sampled stand covered an area of $2.42 \mathrm{ha}$, surrounded by other stands of similar age. The sampled trees were 18 years old at sampling time and had uniform growth conditions. The fire occurred when the trees were 13 years old. The stand 
stocked on a gently sloping terrain with a sparsely distributed understory comprising of grass and low-growing shrubs.

The plantation experienced a surface fire in February 2009. The lower trunk sections of the trees were burnt to a height of about $1.0 \mathrm{~m}$ with char marks still evident at the time of the study, i.e., January 2014. Anecdotal evidence gathered from the stand history records at the local forestry office show that the crowns were not affected. This was confirmed with local foresters and at an inspection of the stand, where no mortality among the charred trees was present that could be associated with crown scorch (e.g., Wade and Ward 1975; Cooper and Altobellis 1969), which is especially relevant in $P$. radiata whose crown is known to be susceptible to crown scorch due to its fine needles (de Ronde et al. 2004a). There was also no evidence of defoliation, scorched dead twigs, or epicormic shoots that could be associated with fire in the sampled stand as opposed to other stands in the burnt area. With no evidence of crown damage, surface fire was assumed to be the cause of possible negative growth among the affected trees. Parts of the stand were evidently unburnt because the fire was stopped at a fire break (Fig. 1b), which prevented it from crossing over to the unburnt section that was subsequently sampled for control.

\subsection{Studied species}

$P$. radiata, which originates from a confined area in Monterey in California, is one of the main commercial species in South Africa and mainly grown for sawlog production (South Africa 2011). It occupies a total area of 59,000 ha and is confined to the Western Cape region (South Africa 2011). P. radiata grows in areas, which would be Fynbos bushland, as a potential natural vegetation form. $P$. radiata thrives on the high winter precipitation experienced in the region (de Ronde 2008a). Plantations in the Cape region often experience fires during the hot summer months between December and March, which are typically characterized also by strong winds. These fires have become a recurrent phenomenon over the past decade due to increased drought conditions and higher temperatures (Calvin and Wettlaufer 2000). The growth season for pines in the Western Cape is limited by temperature and soil moisture availability. No reliable information on pine growth rhythm in this area is available so far, but it can be assumed that the main period for early wood formation is August to December, which is then interrupted by a lack of soil moisture content that goes along with an abrupt formation of latewood.
Fig. 1 a The Jonkershoek fire in 2009 , b a fire break separating the burnt and unburnt stand section, and $\mathbf{c}$ a charred lower trunk section and ash residue (photos: Simon Ackerman)

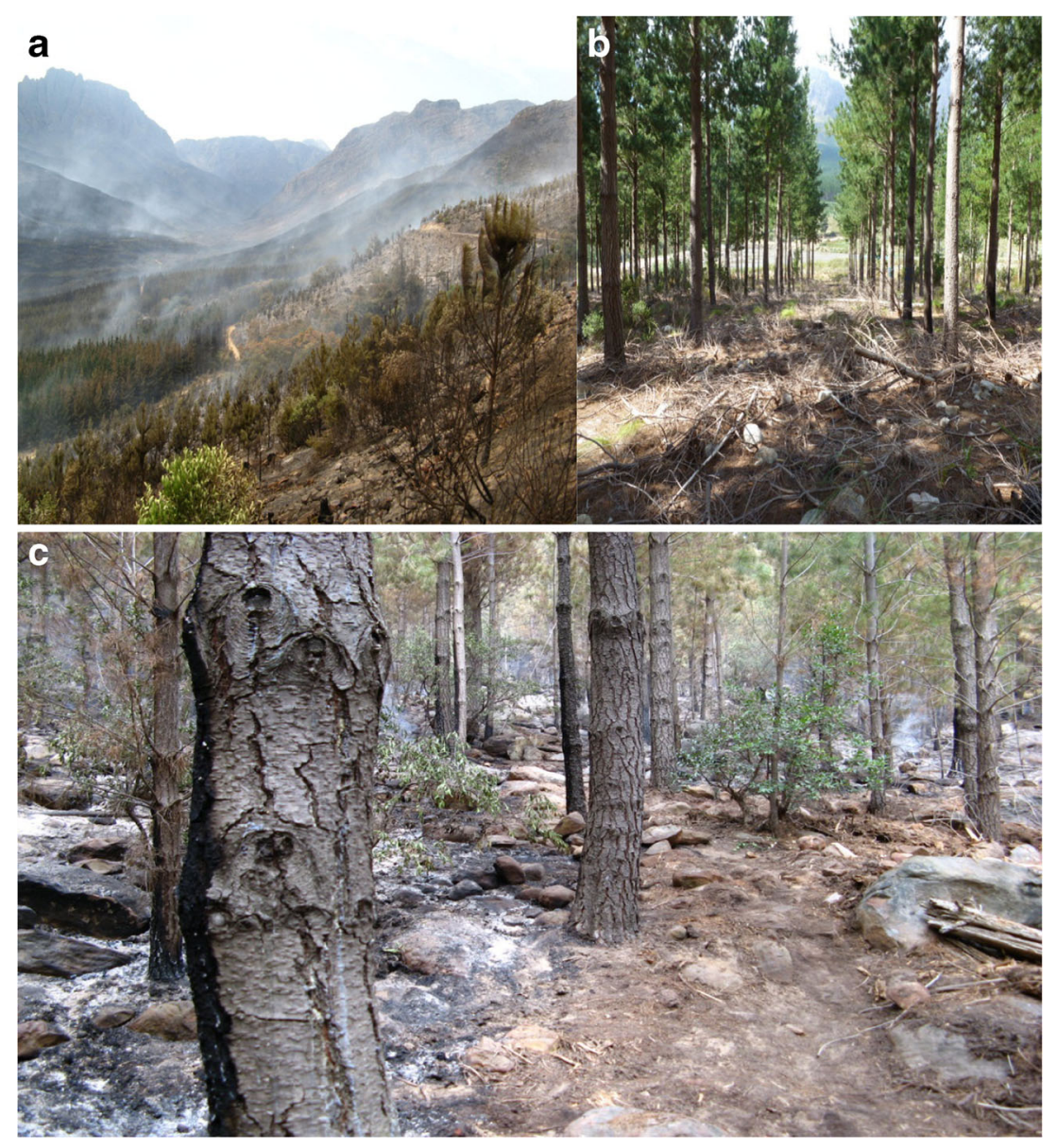




\subsection{Data collection}

Both the burnt and control trees grew in the same stand with similar growth conditions and the same principal management regime. For the study, the stand was divided into two sections, the burnt site and the unburnt control site. The burnt site covered an area of 0.89 ha while the control site had an area of 0.28 ha. 30 trees from each site were selected for the study. The trees on the control site were randomly selected, while those on the burnt site were selected based on the presence of a visible char mark covering more than half of the bole diameter. The entire burnt site was represented in the selection and trees at the boundary rows were excluded to avoid boundary effects. Tree sizes were determined from DBH measurements at $1.3 \mathrm{~m}$ above ground. Fixed area square plots measuring $30 \times 30$ and $25 \times 25 \mathrm{~m}^{2}$ were used for stem density determination in the burnt and control sites, respectively. Six plots within the burnt site and three in control site were selected to represent all areas of the respective sites. The trees in each sample plot were counted, and stand density was determined by averaging the number of trees in the sample plots from each site. The result was then extrapolated to stand density per hectare. Tree rings were measured on increment cores.

The fire came from the north-eastern direction in the burnt site. Two cores were extracted from each burnt and control tree at breast height $(1.3 \mathrm{~m})$, one each from the northern and eastern facing sides of the trunk.

\subsection{Core preparation and tree ring measurements}

In the laboratory, the cores were glued to wooden trays and then sanded with 80 and 400 grit sand paper. Earlywood and latewood dimensions were determined separately for both the pre- and post-fire periods from 2006 to 2013. The tree ring measurements were performed at a resolution of $1 / 100 \mathrm{~mm}$ on a LINTAB TM 6 Tree-Ring Station, in conjunction with the Win-TSAP software (Rinntech, Germany). The impact of the fire on growth was determined from annual basal area increments (iBA) calculated from the growth rings. Annual changes in earlywood and latewood widths were analyzed to gain a better understanding of the role of the fire-induced stress on wood formation, which might not be evident from tree ring width alone (Fonti et al. 2009b, 2010; Matisons and Dauškane 2009).

\subsection{Statistical analysis}

Though analysis of the fire effects hinged on a comparison of burnt and unburnt trees in the same years, changes over time from the pre-fire years 2006-2008, the fire year 2009 and the post-fire years 2010-2013 were quantified.

Differences in DBH between the burnt and control sites, basal area increments, and earlywood and latewood dimensions within each site were tested with one-way ANOVA in SPSS backed up by a nonparametric Tamhane T2-test (Supplement T1). A Wech's $t$ test was used to compare burnt trees vs control for each year and for testing differences in tree dimensions of burnt and control trees. A linear regression was fitted in R (R Core Team 2015) to quantify the relation of basal area increment and precipitation.

\section{Results}

The fact that no needle scorch was observed in 5-m height indicates a lower intensity fire. Based on the heat transfer model of Michaletz and Johnson (2006), who published functions relating needle scorch height to fire intensity, the fire intensity was probably less than $250 \mathrm{~kW} \mathrm{~m}^{-1}$. The fireline had been stopped within the stand leaving parts of the stand stem charred while other parts remained untouched by the fire. However, the unburnt part of the stand and the stem charred part had different stem densities. At the time of the data collection, the burnt site had an average stem density of 344 stems per hectare (standard deviation 43) while the control site had on average 464 stems per hectare (standard deviation 69). However, since individual trees were the sampling unit, the trees were checked for an initial diameter difference. There were no significant differences in tree size $(\mathrm{DBH})$ between trees sampled on the two sites based on Welch's $t$ test (Table 1). Trees from both stands were around $30 \mathrm{~cm}$ in DBH (Table 1). However, the control trees were significantly higher, indicating a slightly better access to water and nutrients, despite the distance between charred and control trees being only around $35 \mathrm{~m}$. The live crown base heights did not differ significantly between the two sampled collectives at around $5 \mathrm{~m}$. Char heights in the fire-affected part of the stand were charred up to $1.0-\mathrm{m}$ height with a standard deviation of $0.3 \mathrm{~m}$ (Table 1).

\subsection{Basal area increment response}

The general growth pattern of both sample sets significantly correlated with the available precipitation (Fig. 2). In the linear regression, which was performed to look into the relationship of mean iBA and mean annual precipitation, the control trees had a slightly higher degree of determination in the linear regression (adjusted $R^{2}=0.75, F$ value $19.38, p$ value $0.007)$ compared to the fire affected trees $\left(R^{2}=0.73, F\right.$ value $16.85, p$ value 0.009 ).

The observed decline in basal area growth on both sites between 2010 and 2011 (Fig. 3) is thus mainly attributed to moisture deficiency due to declining rainfall in those years. However, the decline in basal area growth in 2009 and the recovery in 2011 do not follow the precipitation curve (Fig. 3). 
Table 1 Tree variables of charred and uncharred trees

\begin{tabular}{lllll}
\hline & DBH $(\mathrm{cm})$ & Height $(\mathrm{m})$ & $\begin{array}{l}\text { Live crown base } \\
\text { height }(\mathrm{m})\end{array}$ & Char height (m) \\
\hline Charred trees & 29.4 & 16.9 & 5.0 & 1.0 \\
& $(3.2)$ & $(2.7)$ & $(0.8)$ & $(0.3)$ \\
Uncharred control & 29.4 & 19.4 & 5.2 & - \\
& $(3.5)$ & $(1.2)$ & $(0.5)$ & \\
Welch's $t$ value & 0.018277 & -4.4765 & -1.5619 & \\
$d f$ & 57.659 & 39.675 & 47.872 & \\
$p$ value & 0.9855 (n.s.) & $<0.001$ & 0.1249 (n.s.) & \\
\hline
\end{tabular}

Given are the values and the standard deviation in brackets. A Welch's test on significance of the different variables is added below

n.s. nonsignificant
The annual iBA in the control site clearly exceeded that of the burnt site. Significant differences in iBA between the burnt and control sites were recorded in 20072 years previous to the fire and in 2009 and 2010 (Fig. 3, Table 2). The iBA differences between burnt and unburnt trees in the 2 years following the fire were much higher than those observed in 2007 and the differences in 2010 were more pronounced than in 2009. This indicates that apart from declining moisture levels, the impact of fire further decreased growth on the burnt site causing significant iBA differences between the two sites in the fire year $2009(p<0.009)$ and the following year $(p<0.001)$. A full test statistic of the T2 test can be found in Table 1 of the supplementary material. This indicates that the impact of the fire damage was carried over from 2009 to the following year and alongside moisture deficiency, resulted in the observed low iBA value.

\subsection{Earlywood and latewood response}

The latewood/earlywood ratio at the tree ring gave additional insights into the tree reaction (Fig. 4, Table 3). Before the fire, the latewood/earlywood ratio differed insignificantly between burnt and unburnt trees. In the fire year 2009, the normal pattern was interrupted with a significant decline in earlywood. On the burnt site, the latewood/earlywood ratio in the pre-fire period was similar to that in the trees of the control site indicating a similar growth pattern. However, in the fire year, a significantly increased latewood/earlywood ratio could be observed on the burnt site compared to the control site, despite both sites experiencing the same amount of rainfall in that year. This ratio shift was caused by a reduced earlywood formation on the trees from the burnt site in the fire year. Thus, it was attributed to the fire impact. Unlike the control site, where the latewood/earlywood ratio returned to pre-fire levels in
Fig. 2 Relationship between basal area incrememnnt and mean annual precipitation of the burnt ( $\left.p=0.0093, R^{2}=0.878\right)$ and control $\left(p=0.0070, R^{2}=0.892\right)$ trees. The fitted linear regression lines are nearly identical

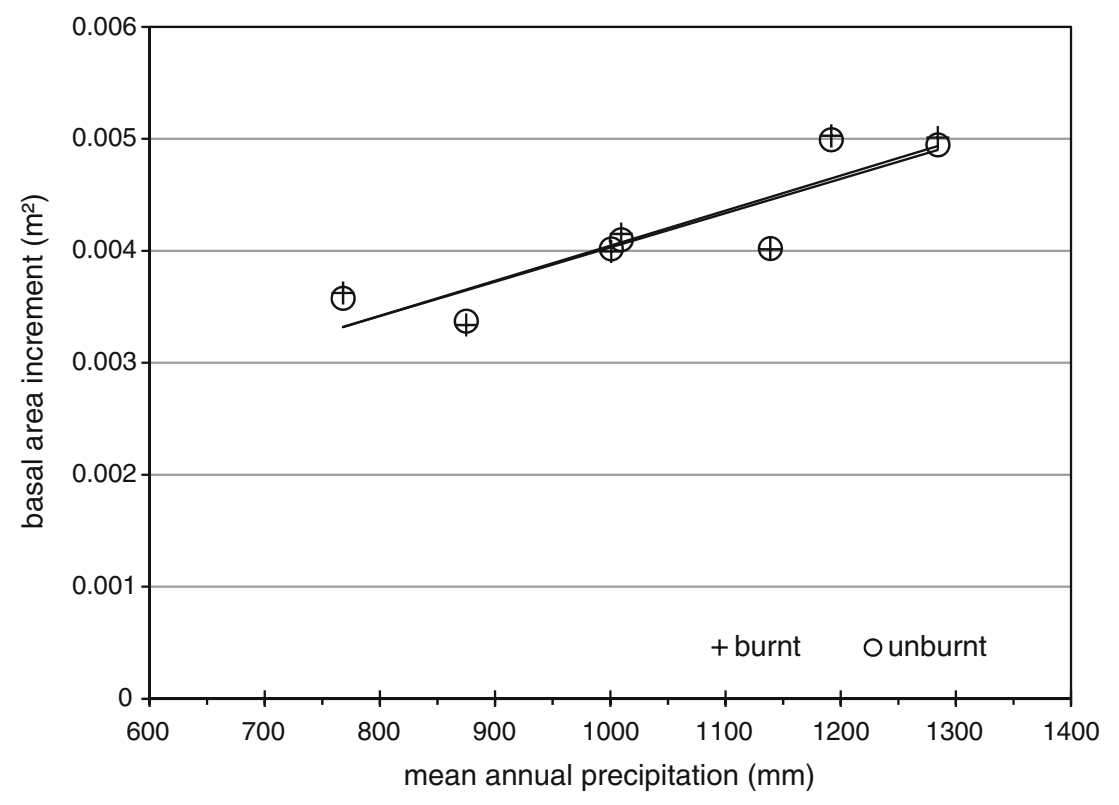


Fig. 3 Comparison of iBA of burnt and control sites. Stars mark the years of significant difference. Displayed are the mean and the 95\% confidence interval.

Additionally, the mean annual precipitation MAP (bars) and is displayed on the right axis. The broken line indicates the average years average MAP

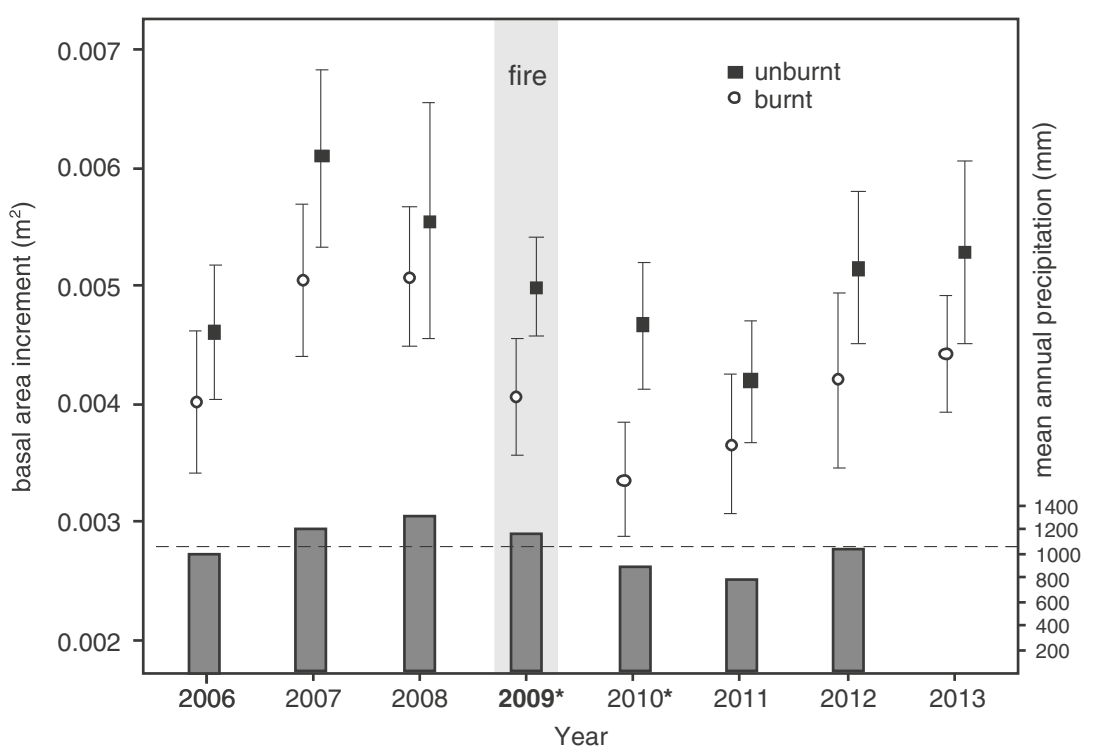

2011, it took until 2012 before the ratio of trees from the burnt site matched pre-fire levels due to the impact of multiple stresses. This was helped by improved moisture levels in 2012.

\section{Discussion}

The burnt and the control sites comprised different sections of the same stand. They were therefore subjected to similar environmental and site conditions, despite some putative advantages of the control site in terms of water supply due to its location at a lower point of the slope. Being part of the same stand, the two sites were subjected to the same management regime. Diameter growth of trees on the control site exceeded that of trees on the burnt site despite a possible higher growth resource competition in the control site due to higher stem numbers per hectare $(26 \%)$. However, by sampling trees that showed a similar DBH on both sites a similar competition regime between the sampled trees was ensured.

\subsection{Basal area increment}

The trees on the burnt site showed a significant reduction in basal area increment in the fire year and the following years,

Table 2 ANOVA derived differences in iBA between burnt and control site

\begin{tabular}{lcccccccc}
\hline Year & 2006 & 2007 & 2008 & 2009 & 2010 & 2011 & 2012 & 2013 \\
\hline$F(1,57)$ & 2.211 & 4.572 & 0.667 & 8.690 & 13.943 & 1.999 & 4.084 & 3.795 \\
$p$ value & 0.143 & 0.037 & 0.417 & 0.005 & 0.000 & 0.163 & 0.148 & 0.056 \\
\hline
\end{tabular}

Significant differences are highlighted in italics which lead to rejection of hypothesis 1 . The precipitation effect showed also a clear influence but affected both sites equally. The growth pattern of trees on both sites conformed to the rainfall pattern. Years 2010 and 2011 were dry years with below average rainfall, which consequently resulted in lower growth in those 2 years. A considerable difference occurred in the fire year and the subsequent year. A dominating water effect on BBA in the fire year 2009 is not very likely since 2009 experienced an average amount of rainfall; hence, fire is the most probable influential factor. There was a further decrease in $\mathrm{iBA}$ in the burnt site in 2010, which was the year with the lowest growth. The concurrent sharp decline in rainfall in 2010 might have been the reason for this. However, the fire in 2009 might also have partially contributed to the low iBA figures in 2010. Diameter growth has been found to be most affected in the year following the fire event (Ford et al. 2010). The impact of the fire damage from 2009 might thus also have been carried over to 2010 contributing to the lowest iBA value despite 2011 recording the lowest rainfall value. The clear tree reaction to heat damage at the stem obtained in this study support findings of Balfour and Midgley (2006), who stated for Savannah trees that the cambial influence and xylem damage might be more likely a cause of tree death than crown scorch and terminal bud damage (see also Michaletz et al. 2012). The losses in basal area growth were in the range of 0.001 to $0.0015 \mathrm{~m}^{2}$ per tree in 2009 and 2010, respectively, leading to a loss in iBA of 25 and $26 \%$, respectively. However, the trees of the control site were clearly higher at the same $\mathrm{DBH}$, which might have affected their allometry. It is known that allometric variables such as the diameter-height relation or the percentage crown length can influence growth (Pretzsch 2009). Additionally, trees of different size and age are known to have different basal area increments. We have tried to eliminate this effect partly by 
Fig. 4 Latewood/earlywood ratios in the growth ring in the control and burnt sites. Displayed are the mean and the $95 \%$ confidence interval

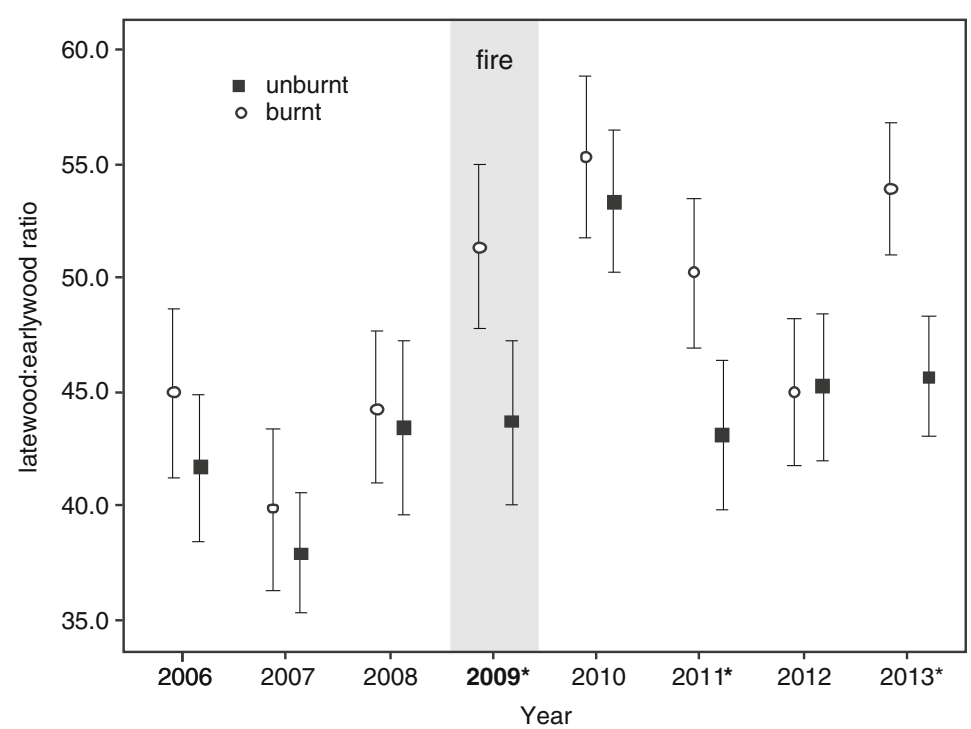

working on even-aged plantations and selecting trees of the same average DBH as control. However, also within each individual tree growth follows an intrinsic age/size-related trend. Increment in basal area typically increases steeply to level off in a plateau and then gradually declines at later ages (Assmann 1970). The maximum iBA is typically reached much later than the maximum ring width since the tree diameter is playing an important role in calculating iBA. From our measured increment patterns, the plateau seems the most likely growth phase of our sample trees. This is also supported by tree ring analyses of older trees in the vicinity of the sampled stands.

The difference in stem numbers per hectare needs to be addressed in this context as well. Trees with more space grow better in diameter (Assmann 1970; Pretzsch 2009). The fact that the fire-affected trees showed a significantly lower growth despite their higher growing space suggests that our findings with respect to reduced basal area increment are rather on the conservative side.

\subsection{Latewood/earlywood ratio}

The burnt trees further showed lower latewood/earlywood ratios as an effect of fire, leading to the rejection of hypothesis 2 . This is particularly relevant to practical forestry since the latewood percentage contributes positively to wood density and thus mechanical strength in pines (Wessels et al. 2015). In conifers, earlywood is composed of cells with larger lumen and thin walls. It forms the first and usually largest part of the annual ring and transports water and dissolved nutrients to the new leaves early in the growing season (Vaganov et al. 2004; Dieterich and Swetnam 1984). The size and density of earlywood cells have been shown to correlate with the physiological vigor of the tree (Fonti et al. 2009b; Thomas et al. 2002).

The expected typical pattern of large earlywood and small latewood bands was observed before the fire in both sites. The same pattern was maintained in the control site in the year of the fire and after the fire incident. The only difference in the control site was in 2010, which had a higher latewood/

Table 3 Welch's $t$ test to compare earlywood and latewood widths between burnt trees and the control

\begin{tabular}{|c|c|c|c|c|c|c|c|c|c|}
\hline Ring section & Year & $t$ value & $d f$ & $p$ value & Ring section & Year & $t$ value & $d f$ & $p$ value \\
\hline \multirow[t]{8}{*}{ Earlywood } & 2006 & 0.34344 & 57.985 & 0.7325 & \multirow[t]{8}{*}{ Latewood } & 2006 & -1.8165 & 50.692 & 0.0752 \\
\hline & 2007 & 0.38113 & 56.609 & 0.7045 & & 2007 & -0.73799 & 55.892 & 0.4636 \\
\hline & 2008 & -0.43533 & 44.502 & 0.6654 & & 2008 & -1.4897 & 54.793 & 0.1420 \\
\hline & 2009 & 2.05020 & 57.998 & 0.0449 & & 2009 & -1.3215 & 57.524 & 0.1916 \\
\hline & 2010 & 2.12320 & 57.420 & 0.0380 & & 2010 & 1.4754 & 54.047 & 0.1459 \\
\hline & 2011 & 1.0684 & 57.211 & 0.2898 & & 2011 & -2.5697 & 49.399 & 0.0132 \\
\hline & 2012 & 0.30239 & 54.959 & 0.7635 & & 2012 & 0.71294 & 52.689 & 0.4790 \\
\hline & 2013 & 2.4371 & 49.886 & 0.0184 & & 2013 & -1.7801 & 57.577 & 0.08034 \\
\hline
\end{tabular}

Significant differences are highlighted in italics 
earlywood ratio due to the drought. In the following year 2011, with the lowest rainfall, the trees readjusted to the drought conditions and restored normal growth in the control site. We hypothesize that the normal latewood/earlywood ratio of the control in 2011 could be an effect of increased water and nutrient supply due to a fire induced reduced stand density upslope as an effect of the fire damage done in the burnt parts of the compartment and the ash intake. However, this remains speculative.

At the burnt site, the expected early and latewood pattern was disrupted in 2009. Increased latewood/earlywood ratios have also been observed following crown scorch in P. halepensis (De Micco et al. 2013). The crowns of the trees in the burnt site were not scorched by the fire and the observed increase in latewood/earlywood ratio is attributed to the stem char. However, root damage caused by the heat impact could not be entirely excluded, despite the fact that the tree grew on sandy soils with low carbon content, which are known to conduct heat rather reluctantly.

In the same year, the control site, which experienced the same decrease in rainfall showed growth with smaller latewood/earlywood ratios. The earlywood width further reduced in 2010 in the burnt site due to drought and the carried over fire effect from 2009. Despite readjustment to the drought conditions in 2011, the multiple stress effect of the fire and drought resulted in unexpected earlywood growth in that year. Normal growth was only restored in the bunt site in 2012 following resumption of average rainfall.

In previous studies, insignificant growth impacts from surface fire damage have been reported (Hempson et al. 2014; Bauer et al. 2010; Ducrey et al. 1996). A study on P. radiata also found no consequences on radial growth of mature trees following surface fire damage and concluded that stem damage does not impact on merchantable wood volume (Fernandes et al. 2008). In this study, however, it was found that even low-intensity surface fires have a negative growth impact on the growth of $P$. radiata trees. Due to the combined effects of both fire and moisture deficit, the impact of fire damage on iBA growth could not be estimated independently. The study was not replicated in other stands due to lack of availability of plantations with similar type and extent of fire damage. The results therefore represent the findings in this stand and could be used in reference to $P$. radiata sites with similar size of trees and stand specifications. Growth reductions due to surface fire damage have, however, been reported for P. strobus by Elliott et al. (2002) and for P. palustris by Ford et al. (2010). This present study has shown that fire can have the same impact on P. radiata.

Growth reduction is realized in the fire year and is also carried over to the following year after the fire event. The study has shown that the trees can be expected to recover from the fire impact in the second year following the fire event. This is similar to the time lag response before complete recovery is restored to approximately pre-fire levels following crown fires (Murphy et al. 2010; Goldammer 2007; Werner 2005; Hoffmann and Solbrig 2003; Werner et al. 2006; Williams et al. 1999). Recovery from crown scorch involves regeneration from epicormic shoots (Bond and van Wilgen 1994) or leaf buds (e.g., Thies et al. 2006) to reestablish the photosynthetic capacity after the fire event. These growth readjustments take place at comparably the same duration as wound healing and tissue repair involved after cambial damage. An unexpected effect on latewood/earlywood ratios was observed in 2013, where the ratios showed significantly higher values on the burnt site after it had already shown a nonsignificant difference compared to the control the years before. We do not expect this to be a fire induced effect but cannot rule it out.

Our results show that in order to fully understand fire impact on growth of $P$. radiata, more studies are needed in order to differentiate the effects of crown, root, and stem damage cause by fire. A better general understanding of wood formation of that species in the environment of investigation would definitely help to analyze the fire-specific effects and should be part of the future research.

\section{Conclusions}

Surface fires can impact on tree growth of $P$. radiata. This study provided evidence that

(1) Surface fire caused reduced basal increments in trees of P. radiata

(2) These growth reductions might be carried to the year following the fire event and can last 3 years before prefire growth levels are restored.

(3) Latewood/earlywood ratios were increased in the year of the fire damage and the following year.

Acknowledgements We want to acknowledge the support of Cape Pine, who provided access to their plantation for our field sampling and supported us with further background information.

This study was supported by the NRF/DST Centre of Excellence in Tree Health Biotechnology (CTHB), the Green Landscapes Project, funded by DST/NRF as well as the SASSCAL project 205 funded by BMBF and DST. We want to express our gratitude for the funding. We want to acknowledge the help of Cape Pine, who provided access to their plantation for our field sampling and supported us with further background information. We also want to thank the two anonymous reviewers and particular Dr. Sean Michaletz for their constructive comments. They have contributed to improve the article substantially. Finally, we would like to thank Dr. David Drew for his helpful comments on the language.

\section{Compliance with ethical standards}

Funding This study was financially supported by the NRF/DST Centre of Excellence in Tree Health Biotechnology (CTHB) and by the Green 
Landscapes Project, funded by DST/NRF. We want to express our gratitude for the funding.

\section{References}

Aldersley A, Murray SJ, Cornell SE (2011) Global and regional analysis of climate and human drivers of wildfire. Sci Total Environ 409: 3472-3481

Arbelley E, Stoffel M, Sutherland EK, Smith KT, Falk DA (2014a) Changes in tracheid and ray traits in fire scars of North American conifers and their ecophysiological implications. Ann Bot 114:223-232

Arbelley E, Stoffel M, Sutherland EK, Smith KT, Falk DA (2014b) Resin duct size and density as ecophysiological traits in fire scars of Pseudotsuga menziesii and Larix occidentalis. Ann Bot 114:973980. doi:10.1093/aob/mcu168

Assmann E (1970) The principles of forest yield study. Pergamon, Oxford, New York

Balfour DA, Midgley JJ (2006) Fire induced stem death in an African Acacia is not caused by canopy scorching. Austral Ecology 31:892896

Bauer G, Speck T, Blömer J (2010) Insulation capability of the bark of trees with different fire adaptation. Journal of Material Science 45: 5950-5959

Blanchette RA (1992) Anatomical responses of xylem to injury and invasion by fungi. In: Blanchette RA, Biggs AR (eds) Defense mechanisms of woody plants against fungi. Springer, Berlin, pp 76-95

Bond WJ, van Wilgen BW (1994) Fire and plants. Chapman and Hall, London

Brown JK (1995) Fire regimes and their relevance to ecosystem management. In Proceedings of the society of American forester's, 1994 national convention, pp. 171-178

Calvin M, Wettlaufer D (2000) Fires in the southern Cape Peninsula, Western Cape Province. South Africa IFFN No 22:69-75

Cooper RW, Altobellis AT (1969) Fire kill in young loblolly pine. Fire Control Notes 30:14-15

De Bano LF, Neary DG, Ffolliott PF (1998) Fire effects on ecosystems. John Wiley \& Sons, USA

De Micco V, Zalloni E, Balzano A, Battipaglia G (2013) Fire influence on Pinus halepensis: wood responses close and far from the scars. IAWA J 34:446-458

de Ronde C (2008a) Knowledge base in damage assessment to forests and plantations. Deliverable D3.2-7 of the Integrated project "Fire Paradox", Project FP6-018505. European Commission, pp 20

de Ronde C (2008c) Knowledge base in damage assessment to forests and plantations. Deliverable D3.2-7 Unpublished paper for FIRE PARADOX WP 3.2: European Commission, pp 20

de Ronde C, du Plessis M (2002) Determining the relative resistance of selected Pinus species to fire damage. In Forest fire research and wildland fire safety. Millpress, Rotterdam, pp 1-9

de Ronde C, Böhmer LH, Droomer AEC (1986) Evaluation of wildfire damage in pine stands. South Afr For J 138:45-50

de Ronde, C., Trollope, W.S.W., Parr, C.L., Brockett, B. and Geldenhuys, C.J. 2004a. Fire effects on flora and fauna. In: Goldammer, J.G. and de Ronde, C. (eds). Wildland Fire Management Handbook for SubSahara Africa: $60-87$

Dickinson MB, Johnson EA (2001) Fire effects on trees. In: Johnson EA, Miyanishi K (eds) Forest Fires. Academic Press, New York, pp $477-$ 525

Dieterich JH, Swetnam TW (1984) Dendrochronology of a fire scarred ponderosa pine. For Sci 30:238-247

Drobyshev I, Niklasson M, Angelstam P (2004) Contrasting tree-ring data with fire record in a pine-dominated landscape in the Komi Republic (eastern European Russia): recovering a common climate signal. Silva Fennica 38:43-53
Ducrey M, Duhoux F, Huc R, Rigolot E (1996) The ecophysiological and growth responses of Aleppo pine (Pinus halepensis) to controlled heating applied to the base of the trunk. Can J For Res 26:13661374

Elliott KJ, Vose JM, Clinton BD (2002) Growth of eastern white pine (Pinus strobus $L$.) related to forest floor consumption by prescribed fire in the southern Appalachians. South J Appl For 26:18-25

Fernandes PM, Vega JA, Enrique J, Rigolot E (2008) Fire resistance of European pines. For Ecol Manag 256:246-255

Fink S (1999) Pathological and regenerative plant anatomy. In: Encyclopedia of plant anatomy, 14 (6), Gebru" der Borntra" ger. Berlin, Germany

Fonti P, Treydte K, Osenstetter S, Frank D, Esper J (2009b) Frequency dependent signals in multi-centennial oak vessel data. Palaeogeogr palaeocl 275:92-99

Fonti P, von Arx G, Garcia-Gonzalez I, Elimann B (2010) Studying global changes through investigation on the plastic responses of xylem anatomy in tree rings. New Phytol 185:42-63

Ford CR, Emily SM, Gordon AF (2010) Long-term effects of fire and fire-return interval on population structure and growth of longleaf pine (Pinus palustris). Can J For Res 40:1410-1420

Fulé PZ (2010) Wildfire ecology and management at Grand Canyon, USA: tree-ring applications in forest fire history and modeling. In: Stoffel M, Bollschweiler M, Butler DR, Luckman BH (eds) Tree rings and natural hazards. Advances in global change research Vol. 41. Springer Verlag, Berlin

Gill AM (1977) Management of fire-prone vegetation for plant species conservation in Australia. Search 8:20-26

Goldammer JG (2007) Forest fires - a global perspective. Global Fire Monitoring Center

Grab S, Craparo A (2011) Advance of apple and pear tree full bloom dates in response to climate change in the Southwestern Cape, South Africa: 1973-2009. Agric For Meteorol 151:406-413

Grissino-Mayer HD (2010) Wildfire hazard and the role of tree-ring research. In: Stoffel M, Bollschweiler M, Butler DR, Luckman BH (eds) Tree rings and natural hazards. Advances in global change research Vol. 41. Springer Verlag, Berlin, pp 329-359

Harris RMB, Remenyi TA, Williamson GJ, Bindoff NL, Bowman DMJS (2016) Climate-vegetation-fire interactions and feedbacks: trivial detail or major barrier to projecting the future of the Earth system? WIREs Climate Change

Hempson GP, Midgley JJ, Lawes MJ, Vickers KJ, Kruger LM (2014) Comparing bark thickness: testing methods with bark- stem data from two South African fire-prone biomes. J Veg Sci. doi:10.1111 /jvs.12171 [August 2014]

Hertel D, Strecker T, Müller-Haubold H, Leuschner C (2013) Fine root biomass and dynamics in beech forests across a precipitation gradient-is optimal resource partitioning theory applicable to waterlimited mature trees? J Ecol 101:1183-1200

Hoffmann WA, Solbrig OT (2003) The role of top kill in the differential response of savanna woody species to fire. For Ecol Manag 180: 273-286

Hood SM, McHugh CW, Ryan KC, Reinhardt E, Smith SL (2007) Evaluation of a post-fire tree mortality model for western USA conifers. Int J Wildland Fire 16:679-689

Hood SM, Cluck DR, Smith SL, Ryan KC (2008) Using bark char codes to predict post-fire cambium mortality. Fire Ecology 4:57-73

Larson PR (1994) Springer series in wood science: the vascular cambium. Development and structure. Springer-Verlag, Berlin

Macias Fauria M, Michaletz ST, Johnson EA (2011) Predicting climate change effects on wildfires requires linking processes across scales. Wiley Interdiscip Rev Clim Chang. doi:10.1002/wcc.92

Makkonen S, Huuhilo K, Utriainen J, Holopainen T, Kainulainen P (2016) Radial ring width and wood structure in the ozone-exposed Norway spruce seedlings grown under different nitrogen regimes. Boreal Environ Res 21:149-165 
Mann ML, Batllori E, Moritz MA, Waller EK, Berck P, Flint AL, Flint LE, Dolfi E (2016) Incorporating anthropogenic influences into fire probability models: effects of human activity and climate change on fire activity in California. PLoS One 11:e0153589. doi:10.1371 /journal.pone. 0153589 eCollection 2016

Matisons R, Dauškane I (2009) Influence of climate on earlywood vessel formation of Quercus robur at its northern distribution range in central regions of Latvia. Acta Univ Latv 753:49-58

Michaletz ST, Johnson EA (2006) A heat transfer model of crown scorch in forest fires. Can J For Res 36:2839-2851

Michaletz ST, Johnson EA (2007) How forest fires kill trees: a review of the fundamental biophysical processes. Scand J For Res 22:500-515

Michaletz ST, Johnson EA, Tyree MT (2012) Moving beyond the cambium necrosis hypothesis of post-fire tree mortality: cavitation and deformation of xylem in forest fires. New Phytol 194:254-226

Murphy BP, Jeremy RS, Lyndad P (2010) Frequent fires reduce tree growth in northern Australian savannas: implications for tree demography and carbon sequestration. Glob Chang Biol 16:331-343

Newton CA (2007) Forest ecology and conservation. A handbook of techniques. Oxford university press, Oxford

Odhiambo BO, Meincken M, Seifert T (2014) The protective role of bark against fire damage: a comparative study on selected introduced and indigenous tree species in the Western Cape, South Africa. Trees 28: $555-565$

Parks SA, Miller C, Abatzoglou JT, Holsinger LM, Parisien M-A, Dobrowski SZ (2016) How will climate change affect wildland fire severity in the western US? Environ Res Lett 11. doi:10.1088/17489326/11/3/035002

Peterson DL, Sackett SS, Robinson LJ, Haase SM (1994) The effects of repeated prescribed burning on Pinus ponderosa growth. Int $\mathrm{J}$ Wildland Fire 4:239-247

Pretzsch H (2009) Forest dynamics, growth and yield from measurement to model. Springer, Berlin

Pyne SJ, Andrews PL, Laven RD (1996) Introduction to wildland fire, 2nd edn. Wiley \& Sons, NY

R Core Team (2015) R: a language and environment for statistical computing. R Foundation for Statistical Computing, Vienna, Austria URL http://www.R-project.org/

Rötzer T, Seifert T, Gayler S, Priesack E, Pretzsch H (2012) Effects of stress and defence allocation on tree growth: simulation results at the individual and stand level. In: Matyssek R, Schnyder H, Oßwald W, Ernst D, Munch J-C, Pretzsch H (eds) Growth and defence in plants. Springer (Ecological Studies, 220), Berlin, pp 401-431

Rozas V, Gonzalo PDL, Ignacio GG, Jose RA (2011) Contrasting effects of wildfire and climate on radial growth of Pinus canariensis on windward and leeward slopes on Tenerife, Canary Islands. Trees 25:895-905

Schweingruber FH (1993) Trees and wood in dendrochronology. Springer Verlag Berlin Heidelberg, Berlin

Schweingruber FH (2007) Tree-ring measurements of Picea mariana (Black spruce) from sample QUEBEC-382. Swiss Federal Institute for Forest, Snow and Landscape Research, available online, DOI: 10.1594/PANGAEA.597213

Seifert T, Nickel M, Pretzsch H (2010) Analysing the long-term effects of artificial pruning of wild cherry by computer tomography. Trees 24 : 797-808

Shinozaki K, Yoda K, Hozumi K, Kira T (1964a) A quantitative analysis of plant form-the pipe model theory. I. Basic analyses. Jpn Ecol 14: 97-105

Shinozaki K, Yoda K, Hozumi K, Kira T (1964b) A quantitative analysis of plant form- the pipe model theory: II. Further evidence of the theory and its application in forest ecology. Jpn Ecol 14:133-139
Smith KT, Arbellay E, Falk DA, Sutherland EK (2016) Macroanatomy and compartmentalization of recent fire scars in three North American conifers. Can J For Res 46:535-542

South Africa (2011) Report on commercial timber resources and primary round wood processing in South Africa. Forest economic services, Pretoria

Stahlea DW, Mushoveb PT, Cleavelanda MK, Roigc F, Haynesd GA (1999) Management implications of annual growth rings in Pterocarpus angolensis from Zimbabwe. For Ecol Manag 124:217-229

Thies WG, Westlind DJ, Loewen M, Brenner G (2006) Predicting delayed mortality of fire-damaged ponderosa pine following prescribed fires in eastern Oregon, USA. Int J Wildland Fire 15:19-29

Thomas FM, Blank R, Hartman G (2002) Abiotic and biotic factors and their interactions as causes of oak decline in Central Europe. For Pathol 32:277-307

Vaganov EA, Hughes MK, Silkin PP, Nesvetailo VD (2004) The Tunguska event in 1908: evidence from tree-ring anatomy. Astobiology 4:391-399

van Mantgem PJ, Stephenson NL, Byrne JC, Daniels LD, Franklin JF (2009) Widespread increase of tree mortality rates in the western United States. Science 323:521-524

van Wilgen BW (1982) Some effects of post-fire age on the above-ground plant biomass of Fynboss (Macchia). J Ecol 70:217-225

van Wilgen BW, Higgins KB, Bellstedt DU (1990) The role of vegetation structure and fuel chemistry in excluding fire from forest patches in the fire-prone fynbos shrublands of South Africa. J Ecol 78:210-222

Varner JM, Putz FE, O’Brien JJ, Hiers JK, Mitchell RJ, Gordon DR (2009) Post-fire tree stress and growth following smoldering duff fires. For Ecol Manag 258:2467-2474

Vega J, Jimeneza E, Vegab D, Ortizb L, Péreza RJ (2011) Pinus pinaster Ait. Tree mortality following wildfire in Spain. For Ecol Manag 261: 2232-2242

Wade DD, Ward DE (1975) Management decisions in severely damaged stands. J For 73:573-577

Wallin KF, Kolb TE, Skov KR, Wagner MR (2003) Effects of crown scorch on ponderosa pine resistance to bark beetles in Northern Arizona. Environ Entomol 32:652-661

Werner PA (2005) Impact of feral water buffalo and fire on growth and survival of mature savanna trees: an experimental field study in Kakadu National Park, northern Australia. Austral Ecology 30: 625-647

Werner PA, Cowie ID, Cusack JS (2006) Juvenile tree growth and demography in response to feral water buffalo in savannas of northern Australia: an experimental field study in Kakadu National Park. Aust J Bot 54:283-296

Wesolowski A, Adams MA, Pfautsch S (2014) Insulation capacity of three bark types of temperate Eucalyptus species. For Ecol Manag 313:224-232

Wessels CB, Malan FS, Seifert T, Louw JH, Rypstra T (2015) The prediction of the flexural lumber properties from standing South African grown Pinus patula trees. Eur J For Res 134:1-18

Westerling AL, Hidalgo HG, Cayan DR, Swetnam TW (2006) Warming and earlier spring increase western U.S. forest wildfire activity. Science 313:940-943

Whelan RJ (1995) The ecology of fire. Cambridge university press, Cambridge

Williams RJ, Cook GD, Gill AM, Moore PHR (1999) Fire regime, fire intensity and tree survival in a tropical savanna in northern Australia. Aust J Ecol 24:50-59 